\title{
СОВРЕМЕНИТЕ МЕТОДИ ЗА ПРЕСМЕТКА НА ТРОШОЦИТЕ КАКО ОСНОВА ЗА ПОДОБРУВАЊЕ НА КОНКУРЕНТСКАТА ПРЕДНОСТ НА КОМПАНИИТЕ Благица Колева, ${ }^{1}$ Оливера Ѓ Гргиева- Трајковска, ${ }^{2}$ Викторија Крстева ${ }^{3}$
}

\author{
${ }^{1}$ Економски факултет, Универзитет „Гоце Делчев“, Штип \\ blagica.koleva@ugd.edu.mk \\ ${ }^{2}$ Економски факултет, Универзитет „Гоце Делчев“, Штип \\ olivera.trajkovska@ugd.edu.mk \\ ${ }^{3}$ Економски факултет, Универзитет „Гоце Делчев“, Штип \\ viktorija.208637@student.ugd.edu.mk
}

\begin{abstract}
Апстракт. Управувањето со трошоците значи нивно рационално намалување со основна цел зголемување на профитабилноста на компаниите. Ефикасното управување со трошоците овозможува реализација на поставените цели на работењето и остварување конкурентска предност на компаниите на пазарот. Ова всушност значи поефикасна употреба на расположивите ресурси и строга контрола на трошоците, преку намалување на активностите што резултираат со високи трошоци. Поради интензивните промени во технологијата и пазарните услови, традиционалните сметководствени системи за пресметка на трошоците станале несоодветни. Тие се појавиле во време кога многу компании имале мал обем на производство, а директната работна сила и материјалите биле главните трошоци на производството. Денес, ситуацијата е значително променета. Компаниите произведуваат во големи размери, директната работна сила има мал удел во вкупните трошоци, а оперативните трошоци се зголемуваат.

Во обид за поефикасно управување со трошоците развиени се бројни современи методи за нивна пресметка, со што се овозможува донесување на оптимални деловни одлуки и зголемување на успешноста во работењето на компаниите.
\end{abstract}

Клучни зборови: трошоци, управување, пресметка, методи, одлучување, современи.

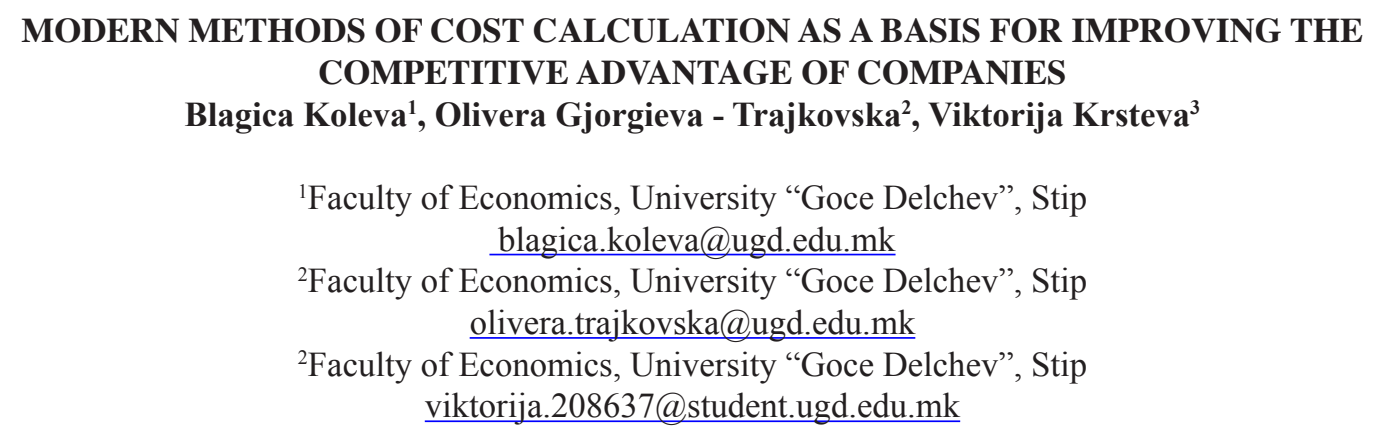

\footnotetext{
Abstract. Cost management means their rational reduction with the main goal of increasing the profitability of companies. Efficient cost management enables the realization of the set goals of the operation and the realization of the competitive advantage of the companies in the market. This actually means more efficient use of available resources and strict cost control, by reducing activities that result in high costs. Due to intensive changes in technology and market conditions, traditional cost accounting systems have become inadequate. They appeared at a time when many companies had a small volume of production, and direct labor and materials were the main costs of production. Today, the situation has changed significantly. Companies produce on a large scale, direct labor has a small share of total costs, and operating costs increase.
} 
In an effort for more efficient cost management, a number of modern methods have been developed for their calculation, which enables the adoption of optimal business decisions and increasing the success of companies.

Kew words: costs, management, calculation, methods, decisions, modern.

\section{Вовед}

Сѐ почестите и интезивни промени на светскиот пазар кои значително се одразуваат на работењето на компаниите, бараат многу поагресивен и посеопфатен пристап во доменот на разбирањето, концепирањето и креирањето на варијаблите кои се од стратегиска важност за нивното работење и зајакнување на конкурентската предност на пазарот. Како последица на ова се зголемува и потребата на компаниите за ревидирање на нивните постоечки информациски системи и насочување на креативните напори кон создавање софистициран, високоинтегриран систем на управување и контрола на трошоците на работењето, како информациска поддршка на менаџментот на компаниите.

Новите филозофии на управување со деловните активности на современите компании настанале првенствено како последица на оскудните информациски перформанси на кои со децении почиваа досегашните класични системи на пресметка на трошоците. Традиционалните системи на пресметка на трошоците креирани да пружат информациска поддршка на менаџментот на компаниите кои работеле во стабилни економии со мали или незначителни турбуленции, не можат повеќе да одговорат на информациските потреби и предизвици кои сѐ повеќе се наметнуваат и стануваат неопходност во современите услови на работење, со изразена конкуренција на пазарот. Оттука, и развојот на новите, современи методи за пресметка на трошоците кои значително придонесуваат за зајакнување на информациската подршка на сметководствениот систем на компаниите.

Современите услови на работење, примената на новите технологии, зголемените барања на потрошувачите и големата конкуренција доведоа до тоа традиционалните методи на пресметка на трошоците да бидат недоволно ефикасни во обезбедување на информации за трошоците на работењето и цената на чинење на производите и услугите на компаниите.

Со цел прецизна алокација на трошоците, покрај традиционалните системи, се развиле и современи системи за пресметка на трошоците, меѓу кои најчесто се среќаваат следните: Activity Based Costing (АВС-трошци на основа на активностите); Target costing (целни трошоци); Just in time (точно на време) систем на пресметка на трошоците; Total Quality Management (менаџмент на вкупниот квалитет) систем на пресметка на трошоците; Backflush систем (опфаќање на трошоците наназад); Cost of quality (трошоци на квалитетот) систем на пресметка на трошоците; Theory of constrains (теорија на препреки); Kaizen техника на пресметка, и др.

\section{Трошоците како основа за менаџерско одлучување}

Управувањето со трошоците (анг. cost management) е дел од целокупниот процес на управување со деловниот успех на компанијата. Од практично искуство и вештини, тоа се развило во наука која ги проучува методите за подготовка и употреба на информации за одлучување. Ги вклучува сите постапки со кои се проценува врската помеѓу трошоците и придобивките во деловното работење на компанијата, со цел да се максимизира профитот на долг рок. Во овој контекст, не е цел на компанијата да се намалат трошоците по секоја цена, туку да се преземат активности, иако тие создаваат трошоци, со помош на кои ќе се обезбеди трајно профитабилен бизнис, односно најголеми можни долгорочни придобивки.

Едуциран менаџер на компанијата знае дека секоја инвестиција во подобрување на функционирањето на организацијата на работењето не е само трошок, бидејќи може да придонесе за подобрување на контролата на трошоците за производство и со тоа да се зголеми профитабилноста. Примери за вакви инвестиции се: набавка на нова опрема, прилагодување и приближување на просторот за складирање, обука на вработените, подобрување на безбедноста при работа. Намалувањето на времето за извршување на работните операции и создавањето поволни услови за работа може да има ефект врз намалување на трошоците на долг рок. Инвестициите во реконструкција и модернизација можат да ги оправдаат зголемените трошоци преку подобрување на профитабилноста. 
Основен менаџерски проблем е како да се постигнат целите на компанијата преку економски ефикасно распределување на ресурсите. При одлучувањето за преземање деловни активности, менаџерите мора да ги следат трошоците со цел, во услови на ограничени ресурси, да ги изберат опциите што носат најголем профит. Информациите за трошоците овозможуваат квалитетно донесување на деловни одлуки за секојдневно работење, како и последователно следење на резултатите од донесените одлуки со цел да се процени успехот и да се контролира нивното извршување.

Воведувањето и популаризацијата на техниките за управување со трошоците се припишува на движењето за научно управување (почетокот на 20 век). Сепак, подоцнежните истражувањаво сметководственитепрактикивобританската металнаитекстилна индустрија, од 1760 до 1850 година, докажале постоење на релативно зрело управување со трошоците во четири главни области на активности: техники за контрола на трошоците, сметководство на трошоците, трошоци за подготовка на рутински и специјални одлуки и пресметка на стандардни трошоци. Управувањето со трошоците е постаро од сметководството на трошоците. До 1950-тите, сметководството на трошоците и управувањето со трошоците имале посебни патишта на развој и оттогаш сметководството на трошоците служело како примарен извор на информации за управување со трошоците [1].

Еден од клучните принципи на управување со трошоците е дека различни трошоци треба да се користат за различни намени. При пресметувањето на трошоците по вид, се проценуваат трошоците класифицирани на нивните природни видови; при пресметувањето на трошоците по центри на одговорност важна е поделбата на трошоците на оригинални и изведени, директни и општи трошоци, како и трошоци за производот и трошоци за периодот; може да се искористат за донесување индивидуални деловни одлуки и сл. [2].

Важна карактеристика на управувањето со трошоците е тоа што обезбедува алокација и доведување во прашање на одговорноста за направените трошоци преку нивно поврзување со менаџерите кои се овластени да донесуваат одлуки за нивното настанување. Затоа, трошоците ги следат организациските делови во компанијата, при што одредено лице е одговорно за работата на секој од нив. Современите процеси на децентрализација на компанијата и автоматизација на деловните процеси го поттикнаа интензивниот развој на системите за управување со трошоците, особено во компаниите кои систематски го менуваат своето работење.

Квалитетот на информациите е важен за менаџерските одлуки. Квалитетот на одлуките во голема мера е одраз на квалитетот на изворите од кои менаџерот добива информации. Најважната сметководствена информација што може да се искористи за управување со еден бизнис е информацијата за трошоците, приходите и финансискиот резултат. Тие се користат за следниве цели: (1) мерење на приходите и трошоците, (2) контрола и (3) алтернативни избори.

Табела 1: Цели и употреба на сметководствените информации

Table 1: Targets and use of accounting information

\begin{tabular}{|c|c|c|}
\hline \multirow[t]{2}{*}{ Цели } & \multicolumn{2}{|c|}{ Употреба } \\
\hline & Податоци од минатото & Проценка на иднината \\
\hline Мерење & $\begin{array}{l}\text { Основа за екстерно } \\
\text { известување } \\
\text { Анализа на економичноста } \\
\text { на извршувањето } \\
\text { Договорни пласмани } \\
\text { според } \\
\text { видови на трошоши }\end{array}$ & $\begin{array}{l}\text { Одлуки во врска со } \\
\text { ценовната политика }\end{array}$ \\
\hline Контрола & $\begin{array}{l}\text { Анализа на } \\
\text { перформансите на } \\
\text { управувањето } \\
\text { Мотивирање и } \\
\text { наградување на } \\
\text { менашерите }\end{array}$ & $\begin{array}{l}\text { Стратешко планирање } \\
\text { Тековно планирање } \\
\text { (буџетирање) }\end{array}$ \\
\hline $\begin{array}{l}\text { Алтернативнииз } \\
\text { бори }\end{array}$ & Нема & $\begin{array}{l}\text { Краткорочни одлуки } \\
\text { Планирање на инвестиции } \\
\text { (буџетирање на капитал) }\end{array}$ \\
\hline
\end{tabular}




\section{1. Карактеристики на традиционалните методи за пресметка на трошоците}

Пресметката на трошоците обезбедува важни информации за управување со компанијата, поради што е исклучително значајно истата да биде навремена и точна, заради донесување навремени и правилни одлуки. Следењето на трошоците за производство е основен предуслов за иницирање на активности за намалување на трошоците во производствениот процес. Процесот на планирање, евидентирање, пресметување и контрола на трошоците на производството се одвива во рамки на дефинираниот систем на трошоци на компанијата. Основните задачи на системот на пресметка на трошоците се:

- идентификување на трошоците по природни видови;

- евидентирање и распределба на трошоците за производство по места на трошоци;

- распределба на индиректните трошоци од споредните и помошни места на трошоци на главните места на трошоци;

- евидентирање и распределба на трошоците на носителите на трошоци (производи);

- одредување на цената на чинење за производството на секој производ.

Со оглед на начинот на распределба на општите трошоци за производство во теоријата на сметководство и практиката се разликуваат:

- традиционален, односно класичен пристап за распределба на општите трошоци за производство;

- $\quad$ модерни (современи) пристапи за распределбата на општите трошоци за производство. Разликата помеѓу традиционалниот и модерниот пристап се состои во начинот на распределба на општите трошоци на производството на носителите на трошоците. Со примена на традиционалниот пристап, општите трошоци на производство се идентификуваат и следат по места на трошоци, а потоа се распределуваат со посебна стапка за распределба на носителите на трошоците. За разлика од традиционалниот, современиот пристап ги идентификува и следи општите трошоци на производство според активностите што ги предизвикале и потоа ги распределува преку низа различни фактори на трошење на носителите на трошоци. Се користи за диференцирање на трошоците на компанијата кои се разграничуваат во неколку основни групи:

- трошоци за директни материјали,

- трошоци за директни плати,

- трошоци на производствена режија,

- трошоци на управна и продажна режија.

Традиционалниот метод за управување со трошоците се обидува да ги опфати трошоците за директни материјали и директни плати, додека режиските трошоци се додаваат на индиректните трошоци. Традиционалниот метод за управување со трошоците се нарекува и традиционален метод за пресметка (калкулација) на трошоците. Традиционалните методи се методи на (пресметки), додека денес во сѐ поголема мера се укажува потребата од целосни системи за донесување одлуки кои класичните пресметки не можат ги задоволат. Бидејќи традиционалните методи сѐ уште се користат, се наведуваат нивните главни недостатоци, а тоа ce:[3]

- ограничена употребливост за донесување одлуки,

- недоволно почитување на пазарот,

- временско поместување,

- мала динамичност.

Традиционалите методи за управување со трошоците ги следат и контролираат директните трошоци за материјали и директната работна сила за секој вид на производ,додека трошоците за производствената и управно-продажната режија се опфаќаат во индиректните трошоци со примена на одредена основа. Имено, за трошоците на производната и управнопродажнате режија се знае местото на трошоците, но не и вистинскиот учинок, поради што се јавува проблемот што да се земе како основа за распределба на општите трошоци на учиноците, за да протокот кој на тој начин ги оптоварува учиноците биде што пореално распределен, т.е. приближен на вистинските општи трошоци што ги предизвикува учинокот. 
Традиционалните методи на управување со трошоците не разликуваат трошоци на производна и управно-продажна режија кај одредени групи на производи. Овие методи може да бидат неточни ако во компанијата голем дел од трошоците не влегуваат во обемот на производството и доколку компанијата произведува широк спектар на производи, во различни количини и со различни степени на сложеност. Исто така е можно пресметката на трошоците на производната и управно-продажната режија врз основа на трошоците за директна работна сила да ја искриви реалната слика на трошоците на одделни производи, особено ако учеството на директните трошоци за работна сила во вкупните трошоци е мало, а во исто време трошоците за производствена и управно-продажна режија се високи.

Сите горенаведени се недостатоци на овој метод кои се голем проблем за менаџерите кои донесуваат деловни одлуки. Примената на овие методи денес е сѐ помала, бидејќи не се погодни за динамичното деловно опкружување во кое работат компаниите денес.

\section{2. Карактеристики на современите методи за пресметка на трошоците}

Потребата од јасно дефинирање на целите на работењето на компаниите е суштинско прашање за неговото позиционирање во економијата, и почнува од поставувањето на неговите долгорочни стратешки цели кои се прецизно и јасно дефинирани и претставуваат движечка сила на деловните активности. Овие цели треба да бидат широко дефинирани за да се опфатат повеќето од интересите на нивните засегнати страни (стејкхолдери).

При дефинирањето на деловните цели, претпријатието треба да земе предвид голем број внатрешни и надворешни фактори. Менаџментот треба да ја избере најповолната стратешка насока од големиот број алтернативи со цел да обезбеди конкурентска предност на пазарот. Покрај менаџментот, во овој процес учествуваат и цели тимови на луѓе од различни области со цел подобро дефинирање на стратегиите.

Земајќи ги предвид сите предности и недостатоци на компанијата, раководството треба соодветно да ги искористи расположивите ресурси и со прифатлив ризик, максимално да ги искористи бројните предизвици на отворената економија, притоа носејќи избалансирани одлуки во светло на организациските промени и можностите што ги нуди околината, како и следење и проценка на стратешкиот и оперативниот развој и врз основа на тоа, да придонесе за реализација на интересите на различните засегнати страни.

Во поново време, сметководството на трошоците има за задача да ги задоволи различните потреби за информации на менаџментот во однос на донесување индивидуални деловни и финансиски одлуки. Оваа задача се однесува на пресметка на трошоците и со користење на cost-benefit анализа, сметководството на трошоците обезбедува извештаи кои содржат релевантни информации за разгледување на алтернативите.

Традиционалните системи за пресметка на трошоци не ја изгубиле својата важност одеднаш, туку во текот на минатиот век. Според Каплан (1984), целата сметководствена практика што се користи денес, била развиена во 1925 година. И покрај значителните промени во природата на организацијата и димензиите на конкуренцијата 60 години подоцна, немало речиси никаква иновативна промена во дизајнот и имплементацијата на сметководството на трошоците. По големата економска криза од 1929 година, фокусот се префрлил од управување со трошоците и оперативната ефикасност кон финансиското сметководство и екстерното известување на компаниите. Сметководителите премногу се грижеле за вредноста на залихите, а не за управувањето со трошоците, што довело до развој на стандардните апсорпциони системи за опфаќње на трошоците, кои преовладуваат во денешните компании.[4]

Менаџерите започнале да ги споредуваат остварените резултати со буџетските бројки при проценката на производните перформанси, што довело до пресметки и развој на отстапувањата во буџетот. Управувањето станало стандардна практика која имала смисла во време на масовно производство и стандардизирани производи. По средината на дваесеттиот век, масовното производство започнало да опаѓа, со воведувањето напредни стратегии за производство што ги следат динамичните промени на пазарот овозможени со флексибилната автоматизација на процесите.

Во услови на развиено производство се зголемува важноста на времето,додека важноста на традиционалните трошочни методи во современото производство се намалува, што било потврдено со изјавата на извршниот директор на GE Aircraft Engines, Schafrik во 2005 година, 
дека начинот на кој остварува успешни инвестиции во иновации е со намалување на времето, а не трошоците, што е потврдено од многу менаџери кои се натпреваруваат на конкурентните пазари и кои ја поддржуваат тезата дека напредните стратегии за производство честопати се поткопани од традиционалните системи за пресметка на трошоците.

Производството засновано на време ја следи сѐ поразвиеното глобално производствено опкружување, во кое што оние кои најбрзо ќе создадат одреден производ или услуга, се оние кои се првиот избор за добивање нарачка од потрошувачите.

\subsection{ABC (Activity Based Costing) метода}

Cooper и Kaplan го вовеле ABC системот за пресметка на трошоците, како подобра алтернатива на распределбата на трошоците и трошоците за производство кои ги нудат традиционалните системи.

За да го развие АВС системот, една компанија треба да: [5]

1. Идентификува кои активности се извршуваат;

2. Да ги распредели трошоците на искористените средства за вршење на одделните активности во трошоковни базени директно или индиректно преку носителите на средствата;

3. Да се распределат трошоците од трошковните базени на активности на производите или други трошочни објекти кои бараат соодветна активност врз основа на трошковниот носител на активност.

Врз основа на овие задачи кои стојат пред АВС системот за пресметка на трошоците, Cooper и Kaplan (1988) поставиле две фази низ кои се одвива истиот:

1. во првата фаза, трошоците се припишуваат на т.н. трошковни базени (cost pools);

2. во втората фаза трошоците од трошковните базени се распределуваат на производите.

Според тоа, АВС системот може да се дефинира преку овој двофазен процес на распределување на трошоците.

Главната идеја на Activity Based Costing (ABC) системот за пресметка на трошоците е да се утврдат реалните трошоци на одделните производи и услуги. Целта на овој систем на трошоци е да ги идентификува нископрофитабилните и непрофитабилните производи и услуги и истите да ги елиминира. Принципот на АВС методот е поделба на организацијата на мали активности и распределување на трошоците за секоја активност врз основа на нивната потрошувачка, т.е. општите трошоци се распределуваат на активности, а потоа врз основа на релевантни основи на производи, врз основа на тоа колку секој производ ја користи таа активност.

Врз основа на основите на овој систем поставени од страна на Cooper и Kaplan (1998), $\mathrm{ABC}$ системот е развиен со цел да се поправат недостатоците во финансискиот систем, особено во неспособноста на традиционалните системи за пресметка да ги идентификуваат носителите на индиректни и општи трошоци.

АВС методот се користи за идентификување на трошоците на производството и профитабилноста. Овој метод се користи како поддршка при стратешкото донесување одлуки, како што се одредување на цените на производите, аутсорсинг, во пронаоѓање на недостатоците и подобрување на производствениот процес, обезбедува финансиски и нефинансиски информации за активностите и за ефективно управување со трошоците. Во фокусот на овој систем за пресметка се активностите и нивните причинско-последични врски со потрошените средства за нив и предизвикувачите на активности.

Сликата во продолжение го илустрира начинот на кој АВС системот се користи за идентификување на трошоците на работењето. 


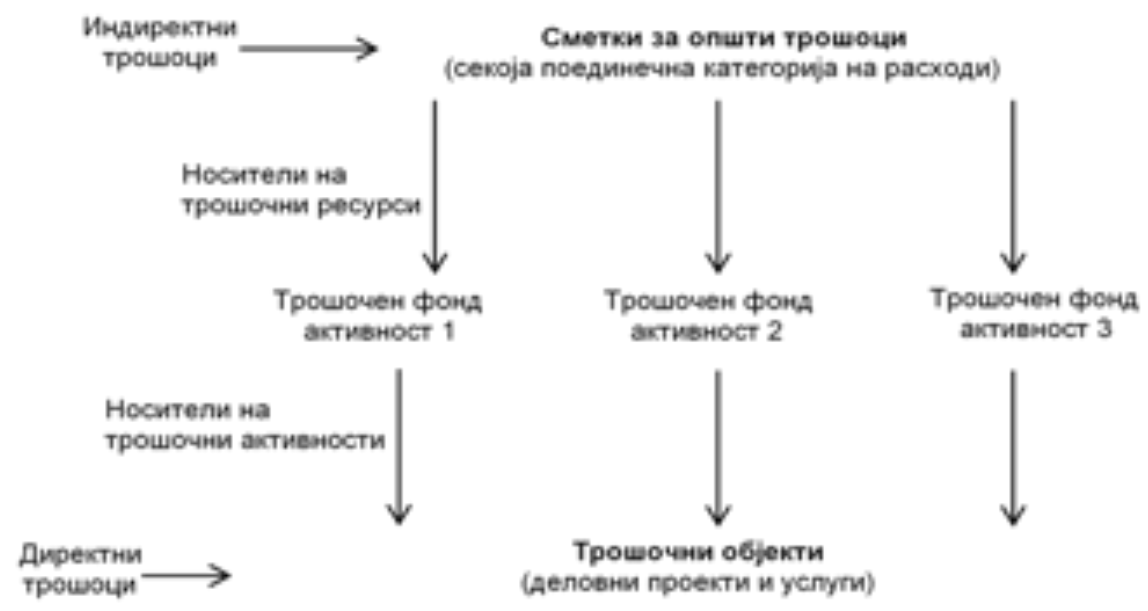

Слика 1: Начин на примена на АВС системот за пресметка во идентификација на трошоци Figure 1: The way of implementation of $A B C$ system of cost calculation in identification of costs

\subsection{TC (Target Costing) метода}

Уште една метода која припаѓа во категоријата на современи методи за пресметка на трошоците е Методата на целни трошоци (Target Costing - TC), која е од понов датум во однос на АВС методата. За да може воопшто да се анализираат целните трошоци, неопхдно е добро познавање и разбирање на постоечката структура на трошоци. Со цел да се реализира одлуката за целните трошоци, истите мора да бидат поделени на поедините делови на производот, што овозможува нивно следење, утврдување на отстапувањата и причините во подоцнежните фази. Притоа се уважува принципот дека трошоците на деловите на производот може да изнесуваат само во висина на придонесот на деловите за корисноста на производот, од аспект на купувачите. На овој начин Моделот на целни трошоци го задржува блискиот однос со потрошувачите, што е посебна одлика на овој модел.[6]

Техниките на целните трошоци претставуваат современа концепција на управување со трошоците, и опфаќаат низа инструменти за планирање и донесување одлуки за структурата на трошоците на производите и услугите. Овој модел се применува во најраните фази на производството, односсно уште во фазата на планирање и развој на производите, а со цел приспособување на производите на потребите и желбите на купувачите.

Методата на целни трошоци е метода за управување со целните трошоци, а прв почнал да ја применува јапонскиот производител на автомобили Тојота во 1963 година. Иако во почетокот оваа метода не била многу применувана, со тек на времето сѐ повеќе јапонски компании почнале да ја применуваат. За време на нафтената криза во 1973 година примената на оваа метода доживеала вистинска експанзија, затоа што во тие тешки моменти се покажала како идеална за производните компании во редуцирање на производните трошоци. Иако нејзината примена е најраспространета во Јапонија, денес ја применуваат значаен број големи европски и американски производни компании.

Примената на Методата на целни трошоци бара одредени вложувања во материјална смисла и ангажирање на стручни лица од различни подрачја (маркетинг, финансии, производство, сметководство и сл.). За ефикасна примена на оваа метода потребно е добро познавање на состојбата на пазарот и негово постојано истражување. Поточно, потребно е добро познавање на желбите на купувачите и колку тие се подготвени да платат за нивно остварување. Имено, овој метод претпоставува дека продажната цена е во доменот на купувачите и дека компанијата нема значително влијание врз неа, иако менаџментот на крајот одредува колкава ќе биде таа цена. На тој начин се спречува излегување на компанијата на пазарот со производи кои нема да ги задоволат купувачите во поглед на квалитетот и цената на производите. 


\subsection{Total Quality Management (Менаџмент на вкупен квалитет) и Just-In-Time (Токму на време) системи за пресметка на трошоци}

Како прва голема промена во основата на конкуренцијата која го поместила вниманието од масовното производство и неговата трошочна ефикасност, била воведувањето на Total Quality Management (TQM). По неговото појавување, тој прво претставувал филозофија заснована на фактот дека квалитетот се зголемува преку постојано подобрување на производствениот процес, мотивација на вработените и донесување одлуки засновани на информации.

TQM се заснова на задоволување на потрошувачите во форма на квалитет на производите, навремена испорака и мерки за квалитетно производство, со цел компаниите да ги остварат поставените цели и посакуваната добивка.

За да се постигне овој квалитет, потребно е да се реализираат одредени трошоци, кои се релативно нова алатка која користи модели што ги поврзуваат овие трошоци со четири типа на трошоци за квалитет:

1. Трошоците направени во насока на спречување грешки во форма на софистицирани системи за производство, производи со висок квалитет;

2. Трошоци поврзани со откривање на недостатоци на производот;

3. Трошоци во производствениот процес во форма на отпаден материјал, недостаток на материјали за работа и неисправни производи;

4. Трошоци по производниот процес што се јавуваат по продажбата, во врска со замена, поправка на неисправни производи или правни работи со незадоволни потрошувачи.

TQM има задача да се произведуваат производи без дефекти, со цел да се намалат вкупните трошоци за квалитет. Голем дел од ова се однесува на потребата деловите и материјалите што се добиваат од добавувачите да бидат без дефекти. Тоа се постигнува преку договори за партнерство со добавувачи, врз основа на кои постои меѓузависност помеѓу нив во однос на етичкото однесување и чувството на доверба.

Just-In-Time (JIT) е концепт кој се појавил кратко време по TQM и е тесно поврзан со него, фокусирајќи се на поефикасно управување со залихите, односно намалување на инвестициите во залихи со нивно минимизирање, зголемување на флексибилноста и елиминирање на целиот отпад во производството и дистрибуцијата. И двата системи на пресметка на трошоците се покажале како многу добри индивидуално користени, меѓутоа постои и одредена синергија помеѓу нив што им овозможува да бидат имплементирани и користени заедно. Нивоата на квалитет обезбедени од TQM се она што му треба на концептот JIT за воведување на неопходните мерки за намалување на нивото на залихи и ефикасно управување со нив, создавајќи можности за подобрување на процесите.

Во својата примена, JIT бара ефикасна координација на функциите за маркетинг, набавки и производство, бидејќи ако сите компоненти на производствениот процес не се одвиваат ефикасно, овој систем не може да ја реализира својата функција. Од оваа причина, многу компании воведуваат флексибилен систем на производство (со помош на компјутери) што им овозможува да произведуваат различни производи со минимални промени во поставките. По поставувањето на JIT системот за пресметка, се утврдува каде автоматизацијата би била корисна и се потенцираат нејзините три нивоа:

1. Компјутерско-нумерички контролирани машини;

2. Флексибилен систем за производство како еден од примерите на автоматизирана ќелија, кој произведува семејство производи, од почеток до крај, со употреба на роботи и друга компјутерски контролирана автоматизирана опрема која овозможува префрлување од производство на еден производ на друг;

3. Компјутерски интегриран систем на производство како највисоко ниво, кој интегрира компјутерски поддржани системи за дизајн, инженеринг и производство, при што сите автоматизирани компоненти се поврзани со централно контролиран информациски систем.

Временски базираниот концепт врз кој се засноваат овие современи системи за пресметка на трошоците се засноваат на брзина и квалитет што не секогаш дозволува најниски цени на производите на пазарот, но доведува до намалени интерни трошоци што овозможува остварување поголема профитабилност на долг рок. 


\subsection{Cost of Quality (Tрошоци за квалитет) систем за пресметка на трошоците}

Од TQM системот се развил Cost of Quality (COQ) системот за пресметка на трошоците, како идеја во пресметката на трошоците да се земе предвид дека работите (производите) не биле изработени како што треба првиот пат. Овој систем за пресметка е дизајниран за јапонските претпријатија да го намалат процентот на неисправни производи на секои милион делови.

Врз основа на овој систем, квалитетот е концепт што значи дека при производство на нешто или обезбедување на услуга треба да се постигне квалитет и точност уште првиот пат, без потреба од измени или дополнувања.

Студиите во различни индустрии претпоставиле дека комапниите не започнале со имплементација на овој систем за пресметка сѐ додека не откриле дека $20 \%$ од вкупните производствени трошоци се направени поради расипувања, дефекти.

Ова не значи дека имплементацијата на овој систем ќе ги елиминира сите трошоци одеднаш, туку овој концепт се заснова на фактот дека мора да се направат промени во управувањето, практиката и организациската култура, а вработените мора да поминат одредена обука за работа на машини. Ова претпоставува големи трошоци, но трошоците за превенција и контрола се пониски од трошоците за внатрешни и надворешни недостатоци.

Постојат многу дебати за ефективноста на воведувањето на COQ, при што јапонските претпријатија имаат аргументи дека нема потреба да се проценуваат овие трошоци, дека е потребно само фокусирање на избегнување грешки. Други ја гледаат вредноста на проценките воведени од COQ и веруваат дека има голем потенцијал за зголемување на профитот на комапниите.

\subsection{Theory of Constrains (Теорија на пречки)}

Протокот како најважна мерка за производните перформанси е предложена во Theory of Constrains (ТОС) од Goldratt Е. (1992). ТОС има големо влијание во теоријата за распределба на производствените трошоци и има многу сличности со JIT системот. Акцентот на овој систем се става на намалување на залихите и производството само кога е неопходно, истиот се залага за bafer - залихи за да се заштитат тесните грла во компаниите. Една од основните задачи на ТОС системот е да се намали времето на текот на производството.

GoldrattE.(1992) восвојатакнигајакритикувалхиперпродукцијаташтотрадиционалните системи на пресметка ја протежираат, создавајќи непотребни производи што се складираат во магацините, додека целта на компаниите треба да биде профитот остварен со производство само на она што ќе се продаде, а не со акумулирање залихи или намалување на протокот, како и зголемување на трошоците за производство, кои не дејствуваат на остварување на оваа цел. Овие мерки треба да обезбедат поттик за претпријатијата да работат подобро, додека мерките на традиционалните системи имаат спротивен ефект.

ТОС подоцна напредувал многу повеќе, од подобрување на производството до подобрување на сѐ. Според Goldratt, сите проблеми можат да се решат со откривање на ограничувањата и нивно отстранување, преку спроведување на процес кој открива кои фактори ги предизвикуваат проблемите. Неговата најинтересна опсервација е изнаоѓање на проблемот и барање на причината зошто тој не бил решен порано. Тој верува дека одговорот на ова е дека различни луѓе имаат различни решенија за оптимизирање на системот и со нивно менување станува многу полесно да се отстранат ограничувањата.

Goldratt сугерира дека TOC треба да биде поддржан со нови и специфични мерки за зголемување на перформансите. Овие мерки се: Throuhput Dollar Days и Inventory Dollar Days.[7]

\section{Заклучок}

Трошоците се основна категорија во работењето на сите деловни субјекти. Во теоријата може да се сретнат голем број видови и класификации на трошоците, поради постоењето на различни компании и дејности, а со тоа и различни деловни активности. Информациите во врска со различните концепти на трошоците ги користи менаџментот на компаниите во различни контести, меѓу кои најважен е процесот на одлучување. Стратегијата за управување со трошоците ги дефинира информациите кои треба да се обезбедат во врска со настанување 
на трошоците и трендовите на нивното движење, со што се овозможува менаџментот на компаниите да донесува ефикасни економски одлуки врз основа на факти. Менаџментот на компаниите има потреба да знае колкави се планираните трошоци на работењето, кои трошоци се неопходни, кои се оптимални, и колку изнесуваат реално настанатите трошоци.

Пресметката на трошоците на учиноците претставува дел од сметководствениот информациски систем на една компанија, а истовремено и пресметковна основа на управувачкото сметководство. Во теоријата и практиката не постои единствено мислење за називот на овој дел од сметководствениот систем. Најчестите називи кои се среќаваат во стручната литература и практика се: сметководство на трошоци, пресметка на трошоците на учиноците, погонско сметководство, интерна пресметка, пресметка на производството, погонска пресметка и сл.

Современите услови на работење создале потреба за воведување нови, концепциски модерни системи за пресметка на трошоците, кои во услови на динамични пазари ќе овозможат донесување на побрзи и попрецизни информации за донесување поефикасни менаџерски одлуки.

Современите методи за пресметка на трошоците имаат различни функции, затоа компаниите врз основа на нивните специфични потреби вршат избор на најсоодветната метода која ќе овозможи остварување на поставените цели во работењето. Во овој дел ќе бидат разработени следните современи методи за пресметка и управување на трошоците: ABC (Activity Based Costing) метода; TC (Target Costing) метода; JIT (Just in Time) метода; TQM (Total Quality Man-agement) метода; Backflush метода; Cost of quality метода; Theory of constrains (теорија на препреки); Kaizen метода.

\section{Користена литература:}

1. Fleischman, R. K. i Parker, L. D.: „British Entrepreneurs and Pre-Industrial Revolution Evidence of Cost Management “, The Accounting Review, Vol. 66, No. 2, str. 361 375., 1991;

2. Karis, M. (2008). Upravljanje troškovima, Ekonomski fakultet, Osijek;

3. Ž. Pajić. Obračun troškova na temelju aktivnosti-ABC metoda, Slobodno poduzetništvo, br. 19, TEB, Zagreb, 2000;

4. Hutchinson, R. "The impact of Time-Based Accounting on Manufacturing Performance", Toledo University, 2007;

5. Grasso, L. "Are ABC and RCAAccounting Systems Compatible with Lean Management", Management Accounting Quarterly, 7 (1), 2005;

6. http://kvaliteta.inet.hr/t_Metode_\%20Drljaca.pdf;

7. Tomkins C. R., Madigan D., May B., Steckelmacher P. "Modern Developments in Cost Management", University of Bath, 1997. 